\title{
Antarctica
}

\section{Treaty goes to wider forum}

\section{Canberra}

THE members of the Antarctic Treaty now seem reconciled to the prospect that the future of the treaty will be debated by the United Nations (UN) General Assembly, most probably towards the end of November. The underlying issue is whether exploration and possibly exploitation of Antarctica should rest with the signatories of the Antarctic Treaty or be thrown open to a larger group of states.

At the meeting of the non-aligned nations in Delhi, India, earlier this year, there were several expressions of discontent about the alleged exclusiveness of the Antarctic Treaty. The issue was raised in the UN General Assembly on 14 October by the Deputy Prime Minister of Malaysia, Dato Musa Hitam, who denounced the treaty as "restrictive and exclusive". Malaysia's contention is that Antarctica, like the deep ocean bed, should be regarded as part of the "common heritage of mankind" and should be made accessible to all nations irrespective of "their economic and scientific development and capabilities".

Malaysia's objections have to some extent been undermined, however, by the admission of India and Brazil as full members of the Antarctic Treaty on 12 September, in time to take part in the regular consultative meeting of the treaty members held in Canberra from 13 to 27 September. The two countries have qualified by means of scientific expeditions to Antarctica, India in the past two seasons and Brazil in 1982-83.

In a new departure, representatives of states that have signed the treaty but which have not been admitted as "consultative parties" on the basis of their demonstrated

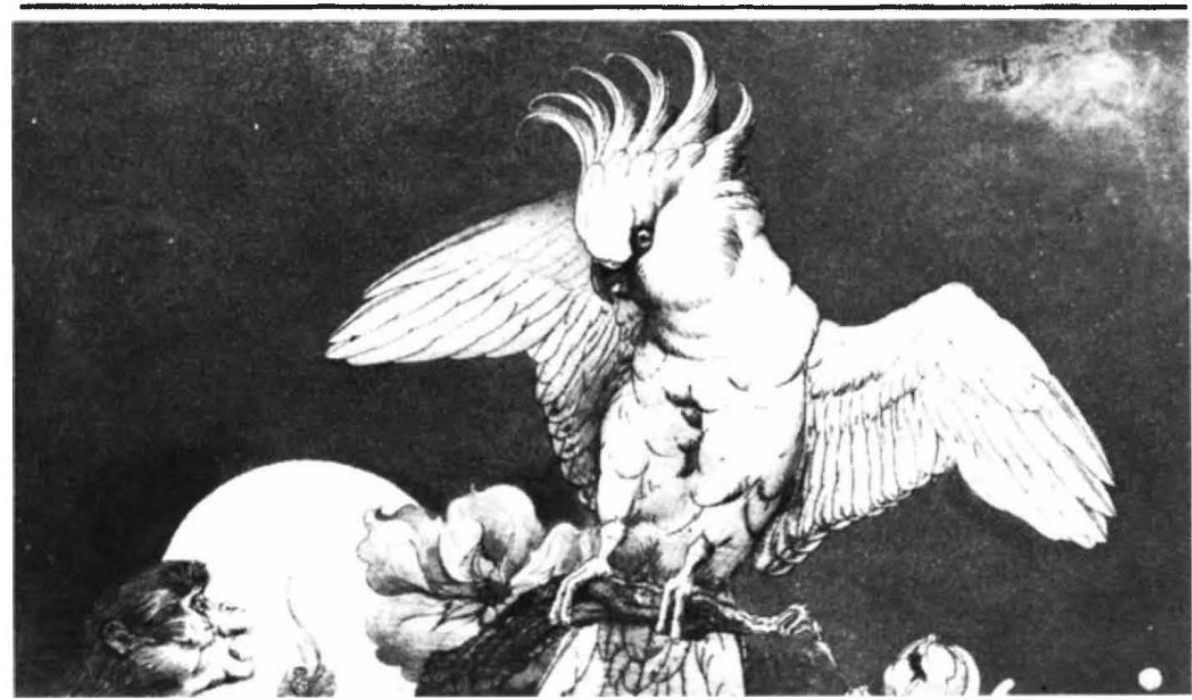

An exhibition at Heslington Hall, University of York, celebrates the centenary of the animal artists Charles Maurice and Edward Julius Detmold. "Cockatoo and Monkey", shown above, was painted by Edward Julius in 1924. The exhibition is in York until 18 November, at the University Art Gallery in Notting ham from 25 November to 17 December and at the British Museum (Natural History) in London from 6 January to 4 February 1984.

interest in Antarctica were present in Canberra as observers. Conspicuous among these was China, which has established a national committee for Antarctic research, which is thinking of applying to join the Scientific Committee for Antarctic Research (SCAR) organized by the International Council of Scientific Unions (ICSU) and which seems to seek the status of a consultative party.

The views of the existing parties to the treaty on the forthcoming UN debate are probably accurately represented by the statement by Mr Bill Hayden, Australia's Minister for Foreign Affairs, at the opening of last month's meeting. The Antarctic Treaty is "alive and well", he said, and any attempt at renegotiation would "introduce uncertainty and confusion into a region of hitherto unparalleled international cooperation".

The most likely outcome of the first UN debate next month is that the secretarygeneral will be asked to carry out an investigation and to report back next year. What happens afterwards is an open question.

Vimala Sarma

\section{Correction}

MR Barrie Jones, Minister of Science and Technology in the Australian Government, denies that he had sought opinions on the future of the Australian National Animal Health Laboratory "from private individuals and the bureacracy without discussion with CSIRO', as reported in Nature on 22 September (p264). In a telegram to our Canberra correspondent, Mr Jones says "This is not true". His statement is gladly accepted. - Editor, Nature 